\title{
Yield of Rainfed Finger Millet under Selected Agronomic Practices: A Study in Southern Dry Zone
}

\author{
D. P. P. Liyanage ${ }^{1^{*}}$, L. M. Abeywikrama ${ }^{2}$ and S. D. Wanniarachchi ${ }^{3}$
}

${ }^{1}$ Grain Legume and Oil Crops

Research and Development

Center, Department of

Agriculture, Angunakolapelessa, Sri Lanka

${ }^{2}$ Department of Agricultural Economics, Faculty of

Agriculture, University of

Ruhuna, Mapalana,

Kamburupitiya, Sri Lanka

${ }^{3}$ Department of Soil Science,

Faculty of Agriculture, University

of Ruhuna, Mapalana,

Kamburupitiya, Sri Lanka

\section{Correspondence:}

*deepanippl@yahoo.com

D https://orcid.org/0000-0003-2863-5158

DOI: http://doi.org/10.4038/sljae.v3i2.54

\section{Abstract}

The farmers in Southern dry zone in Sri Lanka are cultivating finger millet mostly under rainfed condition and majority of them practice random broadcasting for crop establishment. The yield obtained by the conventional rainfed farmers is considerably lower. Already there are available a number of improved low cost approaches can enhance the yield in a sustainable manner but such techniques are not used by the farmers in the rainfed farming systems. This study was carried out to enhance the finger millet yield by introducing some agronomic practices with a high yielding variety (Rawana), row seeding in $30 \mathrm{~cm}$ spacing, application of half of basal fertilizers recommended by Department of Agriculture (DOA) in Sri Lanka, with compost at the rate of $2 \mathrm{Mg} \mathrm{ha}^{-1}$ and practicing two weeding at third and sixth weeks from planting. Sustainable Agronomic Package of Practices (SAPP) was developed during 2014/2015 and 2015/2016 Maha seasons. Then farmer field demonstrations were conducted during 2016/2017 and 2017/2018 Maha seasons and developed SAPP was compared with traditional farmer practice. Results revealed that the yield can be increased by $165 \%$ to $182 \%$ by following SAPP with transplanting and sowing at $30 \mathrm{~cm}$ spacing compared to the yield to the farmer practice and it was $200 \%$ and $220 \%$ respectively compared to the estimated average finger millet yield of $1.3 \mathrm{Mg} \mathrm{ha}^{-1}$ in Sri Lanka.

Keywords: Agronomic practices, Dry zone, Package of practices 


\section{Introduction}

Finger millet is a continuously grown crop in every Maha season under rainfed farming systems in Sri Lanka. It is grown without using organic or inorganic fertilizers under rainfed condition. On the other hand, the degradation of soil properties due to continuous cultivation in same lands resulted in decreasing the productivity of crops. It has caused less farmer income for rain fed finger millet cultivation. Finger millet is a crop belongs to family Poaceae, it has been identified as a promising crop that can survive well in drought prone environment. And it assures income for farmers even under the frequent situations of drought in the dry zone. According to agro ecological classification in Sri Lanka, there are eight main soil types in Hambantota District (Punyawardena et al. 2003). The most widely distributed, and perhaps the most important among them are the Reddish Brown Earths (RBE) and Low Humic Gley (LHG) soils. To increase the production and supply of finger millet, rural households must have access to sustainable technologies and practices that make it easier to cultivate (Raizada 2015). There is a wide yield gap of finger millet between research stations and farmer fields. Even though, a number of low cost approaches are existing to address the problems of soil fertility, water management and plant protection in a sustainable manner but they are not to be exploited for conditions experienced by small farmers (Monje and Raizada 2011). Therefore, it is needed to improve farmer awareness of available technologies and innovations. Liyanage et al. (2015) reported that, there are four categories of constraints faced by finger millet farmers which are production, harvest, post-harvest and marketing related constraints and the farmer awareness and use of improved practices to enhance the yield is very low in Southern dry zone, only $16.7 \%$ of farmers are using simple agronomic practices focused on high yield.

Rhizada (2016) reported that developing sustainable agriculture kits represent a comprehensive approach for sustainability, with one main goal to generate profit for poor farmers in most desperate nations of the world. Sustainable agriculture package developing process, specially determine what are the local needs of the particular country. It should be done by improving farmer awareness of technologies which leads for high yield such as improved varieties, improved agronomic practices, pest control measures etc. 
This study focused to review the nature of Sri Lankan farmers' by engaging them in diverse experimentation activities to adapt for improved available technological packages. The main objective of this research was to enhance the yield of finger millet in the Southern rain fed dry zone farming system in Sri Lanka by developing and disseminating a SAPP with following specific objectives.

1. To determine impact of planting methods and varieties on yield of finger millet

2. To determine effects of different fertilizer applications on yield of finger millet

3. To determine the effects of weed control methods on yield of finger millet.

\section{Materials and Methods}

The research project was carried out at farmer fields under rain fed farming system in Thanamalwila, Hambantota and Angunakolapelessa divisional secretariat areas from 2013 to 2018 during the Maha seasons. The study areas belong to Hambantota and Moneragala districts. The experimental sites belong to DL1b and DL4 agro-ecological regions in the dry zone. The agro ecological zone is characterized by a bimodal rain fall pattern. Expected annual rainfall in DL4 agro-ecological zone is higher than $650 \mathrm{~mm}$ and in DL1b it was higher than 750mm (Punyawardane et al. 2003). And the main cultivation season is Maha season, when rain is fed by North-East monsoon. For identification of soil conditions in the area under the research soil samples were collected from 41 locations in the area under the research project in 2014 and analyzed for few physical and chemical properties. It was found that the soil types of the area under the research were varied from sandy loam to clay loam. According to the IITA soil classification (1982) available organic matter in soil (2.32-3.8\%) was moderate in the area, available $\mathrm{N}$ was low (0.05-0.15\%), and available $\mathrm{P}$ (6.79-23.25ppm) and $\mathrm{K}$ (85.11 - 527.4ppm) were moderate to high in the soil of the area under the research.

Farmers who are cultivating finger millet and who are willing to join with the action research programme were selected for the study. Research trials were conducted using Randomized Complete Block Design (RCBD), with one replicate allocated per farmer. These experiments were researcher designed but farmer managed. Recommended available technologies were used with some modifications at developing the SAPP. Single practice was introduced at the beginning to the farmers and a number of practices were introduced to the farmers as a package. Research was initially implemented in 2014/2015 Maha season 
with the focus of compilation of package practices. Separate research experiments were conducted to select suitable varieties, planting practices, applicable method of fertilizer application and suitable weed control measures which can be used to enhance yield of finger millet cultivation under rain-fed farming conditions.

\section{Impacts of Planting Practices and Varieties on Yield}

Farmer field trials were conducted to select a suitable planting method for finger millet cultivation and evaluated the yield performances of Ravi, Rawana and Oshada, recommended by DOA with popular traditional finger millet cultivar named Kirikurakkan. Transplanting of three weeks old plantlets in $30 \mathrm{~cm} \times 15 \mathrm{~cm}$ spacing ensuring 25 plants $\mathrm{m}^{-1}$ and sowing seeds in rows with $30 \mathrm{~cm}$ spacing at the rate $5 \mathrm{~kg}$ seeds ha-1 were used as improved planting practices compared with the farmer practice of random broadcasting with seeds at the rate of $8 \mathrm{~kg} \mathrm{ha}^{-1}$ (Control) in the trials.

Farmer field research trials were established in four locations in both 2014/2015 and 2015-2016 Maha seasons as single factor experiments and the yields of tested varieties with above mentioned three planting methods were considered for evaluation, plot size allocated for a treatment was $3 \mathrm{~m} \times 5 \mathrm{~m}$ in experimental plots in both seasons. Statistical analysis was done by using SAS 9.1.3 portable software and performed ANOVA to analyze the yield data and mean separation was done by using Duncan's multiple range test (DMRT).

\section{Determination of Effects of Different} Fertilizer Applications on Yield of Finger Millet

Farmer participatory experimental trials were conducted with the focus of find out suitable, cost effective and applicable fertilizer application methods. Experimental trials were established using the variety Rawana in five farmer locations in both 2014/2015 and 2015/2016 Maha seasons.

Plot size of the experimental trials was $15 \mathrm{~m}^{2}$ $(5 \mathrm{~m} \mathrm{X} 3 \mathrm{~m})$ at farmer field trials. Each and every selected farmer location was established with one set of following treatments.

T1 - Application of liquid fertilizer* before booting stage

T2 - Application of inorganic fertilizers recommended for finger millet**

T3 - Application of half a dose of recommended basal application of 
inorganic fertilizers with compost 2 Mgha $^{-1}$

T4 - Application of compost*** 2 Mgha- $^{-}$

${ }^{1}$ before sowing seeds

T5 - No application of inorganic fertilizer or compost (Control)

*Used a market available liquid fertilizer with $\mathrm{N} 7 \%, \mathrm{P}_{2} \mathrm{O}_{5} 13 \%$ and $\mathrm{K} 2 \mathrm{O} 34 \%$ as a foliar application at booting stage

** 50 kgha $^{-1}$ each of Urea, Triple super phosphate and Muriate of Potash as basal application $50 \mathrm{~kg}$ of Urea as top dressing at booting stage

*** Compost used for this study was produced by using green plant materials (leaves from cassava, Gliricidia and Guinea grass), dry plant materials of (crop residues of maize and groundnut) and animal material (cow dung) as the 2:2:1 ratio. Nutrient composition of the compost was $9.94 \%$ of $\mathrm{N}, 0.35 \%$ of $\mathrm{P}$ and $0.58 \%$ of $\mathrm{K}$.

Each location was considered as a block or replicate and plot yield was collected. Statistical analysis was done by using SAS 9.1.3 portable software and performed ANOVA to analyze the yield data and mean separation was done by using DMRT.

\section{Determine the Effects of Weed Control Methods on Yield}

Trials were conducted at farmer fields in 2014/2015 and 2015/2016 Maha seasons. Eight farmer locations were selected in 2014/2015 Maha season to conduct trials. Different eight locations were selected to establish farmer field trials in 2015/2016 Maha season. Only one set of treatments established using the variety Rawana and each location was considered as a block for statistical analysis. All the treatments were maintained with agronomic practices as recommended by the DOA other than the weed control method. Treatments were as follows

$\mathrm{T} 1$ - Row sowing + 2manual weeding at 3 \&6weeks after sowing (WAS)

T2 - Row sowing + selective herbicide* application at 3 WAS

T3 - Row sowing + Mulching

T4 - Row sowing + no weeding

T5 - Random broadcasting + 2 manual weeding at $3 \& 6$ WAS

T6 - Random broadcasting + selective herbicide application at 3 WAS

T7 - Random broadcasting + Mulching T8 - Random broadcasting + no weeding *MCPA 60

Yield data were collected and analysis of variance (ANOVA) was conducted using SAS 9.1.3 software (SAS 2004). 
Test Effect of Developed Sustainable Agronomic Package of Practices on Yield of Rain-Fed Finger Millet

After completion of farmer participatory action research in farmer fields in 2014/2015 and 2015/2016 Maha seasons, SAPP was compiled with following practices

1. Improved variety "Rawana" recommended by DOA

2. Transplanting or Sowing seeds in $30 \mathrm{~cm}$ apart rows

3. Application of half of DOA recommended basal application of fertilizers with 2Mt/ha of compost

4. Two manual weeding at three and six WAS to control weeds

In $2016 / 2017$ and $2017 / 2018$ Maha seasons SAPP was tested in the farmer fields. In these trials yield benefits of SAPP were evaluated comparing farmer practice (random sowing, no application of fertilizers and no proper weeding). Trials were established in six locations in 2016/2017 and 2017/2018 Maha seasons at farmer fields.

Selected farmers were advised to establish 3 plots at their fields, with three plots to test the SAPP with transplanting and sowing seeds in rows and farmer's cultivation practice in the area. Each farmer location was considered as a block or replicate for performing statistical analysis. Yield data was collected in randomly selected 1 sq.m area from three locations / plot and collected yield data were subjected to the analysis of variance (ANOVA).

\section{Results and Discussion}

\section{Evaluation of Impacts of Planting Practices and Varieties on Yield}

Due to wild animal damage only 7 trials out of 12 in the 2014-2015 Maha season and 4 trials out of 7 in 2015-2016 Maha season were considered for the final evaluation. Collected yield data from farmer field trials in 2014/2015 and 2015/ 2016 Maha seasons were showed in Table 1.

According to the yield data in 2014/2015 Maha season (Table 1) treatments were showed significant differences. The yield with transplanting was significantly higher than other practices (row sowing and random broadcasting).

In 2015-2016 Maha season (Table 1) showed approximately same pattern of yield performance as in 2014-2015 Maha season.

All four varieties showed significantly better yields with row sowing in $30 \mathrm{~cm}$ spacing than random broadcasting in both seasons (Table 1). 
Table 1: Yield data of tested varieties with different planting methods in 2014/2015 and 2015/2016 Maha seasons

\begin{tabular}{|c|c|c|c|}
\hline $\begin{array}{l}\text { Planting } \\
\text { method }\end{array}$ & Variety & $\begin{array}{c}\text { 2014/2015 Maha season } \\
\text { Mean yield ( } \text { g plot }^{-1} \text { ) }\end{array}$ & $\begin{array}{c}\text { 2015/2016 Maha season } \\
\text { Mean yield ( } \text { ( plot }^{-1} \text { ) }\end{array}$ \\
\hline \multirow[t]{4}{*}{ Transplanting } & Oshada & $2325.0 \mathrm{ab}$ & $2550.0 \mathrm{ab}$ \\
\hline & Ravi & $2412.5 \mathrm{ab}$ & $2012.5 \mathrm{bcd}$ \\
\hline & Rawana & $2600.0 \mathrm{a}$ & $2637.5 \mathrm{a}$ \\
\hline & Kiri kurakkan & $2225.0 \mathrm{abc}$ & $2212.5 \mathrm{abc}$ \\
\hline \multirow[t]{4}{*}{ Row Sowing } & Oshada & $1750.0 \mathrm{abcd}$ & $2475 \mathrm{ab}$ \\
\hline & Ravi & $1950.0 \mathrm{abcd}$ & 1862.5 cde \\
\hline & Rawana & $2075.0 \mathrm{abc}$ & $2400 \mathrm{abc}$ \\
\hline & Kiri kurakkan & $1900.0 \mathrm{abcd}$ & 1600 def \\
\hline \multirow[t]{4}{*}{ Broadcasting } & Oshada & $1375.0 \mathrm{~cd}$ & 1375 efg \\
\hline & Ravi & $1562.5 \mathrm{bcd}$ & $1125 \mathrm{fg}$ \\
\hline & Rawana & $1937.5 \mathrm{abcd}$ & 1475 defg \\
\hline & Kiri kurakkan & $1162.5 \mathrm{~d}$ & $1025 \mathrm{~g}$ \\
\hline CV\% & & 27.11 & 19.0 \\
\hline
\end{tabular}

Within the mean yield column, the means followed by the same letter are not significantly different

The results revealed that the yields per unit area of land has increased by adoption of improved cultivation practices and row sowing permits easy weed control and higher yield.

Yayeh and Fekremariam (2014) reported that when sowed finger millet seeds in rows with spacing $30 \mathrm{~cm}$ leading for higher yield compared to the closer spacing of random broadcasting. Sowing seeds in rows is a good practice for rain fed finger millet cultivation because it leads for good yield and the requirement of labor is lesser than transplanting. Rhizada (2015) reported in
India, an increase of yield of small millets by $50-64 \%$ with row sowing in furrows compared to seed broadcasting. Row sowing for crop establishment, DOA recommended variety Rawana and farmer using traditional variety Kiri kurakkan showed better yield compared to the DOA recommended varieties Oshada and Ravi. Compared to the other varieties, variety Rawana showed better yield when broadcasting seeds at crop establishment. According to the results yields of tested varieties, irrespective of planting practices, the variety Rawana has showed better yield performances. 
Variety Oshada is recommended for cultivation under supplementary irrigation because it is a longer crop duration and its potential yield is 3 to 3.5 Mgha- $^{-1}$ (agridept.doa.gov.lk).

However, it was not suitable for rain fed farming because of its long duration and requirement of more water. Variety Rawana matures early and gives good yield. Most of the farmers in the dry zone prefer to cultivate finger millet during the North East monsoon (Maha season) which is giving $2 / 3$ of annual total rain fall (Senanayake 2001).

Higher rainfall leads for higher relative humidity of atmosphere, which is more favorable for fungal diseases. Finger millet is attacked by leaf blast (fungal disease) mainly during Maha season. Variety Ravi is susceptible for leaf blast disease and not suitable for Maha season with higher rain fall (agridept.doa.gov.lk).

Farmers like to cultivate traditional variety, kiri kurakkan for consumption because it is having a good taste, but for better income higher yield is important. DOA recommended variety Rawana which is a short aged, high yielding and less susceptible for diseases, to choose as a suitable variety for rain fed cultivation.
Determination of Effects of Different Fertilizer Applications on Yield of Finger Millet

Collected yield data of 5 locations in 20142015 and 2015-2016 Maha seasons were shown in Table 3.

According to the results in both 2014/2015 and 2015/2016 Maha seasons, the finger millet crop was given better yields with both treatments which applied recommended dose of inorganic fertilizers and applied half a dose of basal application of inorganic fertilizers with compost at the rate of 2 Mgha $^{-1}$ Yields of the treatments with applied one dose of liquid fertilizers and only applied compost at the rate of $2 \mathrm{Mgha}^{-1}$ were lesser compared to the treatments with inorganic fertilizers; the lowest yields were showed at the treatments not applied fertilizers in both seasons.

The obtained yields in 2015/2016 Maha season were somewhat lower than the 2014/2015 Maha season due to the drought condition in the season but both seasons' data showed similar patterns (Table 2).

Results revealed that application of fertilizers is important to get better yield. 
Table 2. Yield with different fertilizer applications in 2014/2015 and 2015/2016 Maha seasons

\begin{tabular}{|c|c|c|}
\hline \multirow[t]{3}{*}{ Treatments } & \multirow{2}{*}{$\begin{array}{l}2014 / 2015 \\
\text { Maha season }\end{array}$} & \multirow{2}{*}{$\begin{array}{l}2015 / 2016 \\
\text { Maha season }\end{array}$} \\
\hline & & \\
\hline & $\begin{array}{l}\text { Mean yield } \\
\left(\text { g plot }^{-1}\right)\end{array}$ & $\begin{array}{l}\text { Mean yield } \\
\left(\text { g plot }^{-1}\right)\end{array}$ \\
\hline Application of liquid fertilizer before booting stage (T1) & $3080 \mathrm{~b}$ & $1320.0 \mathrm{~b}$ \\
\hline $\begin{array}{l}\text { Application of inorganic fertilizers recommended for } \\
\text { finger millet (T2) }\end{array}$ & 4210 a & $2160.0 \mathrm{a}$ \\
\hline $\begin{array}{l}\text { Application of half a dose of recommended basal } \\
\text { application of inorganic fertilizers with compost } 2 \mathrm{Mgha}^{-} \\
{ }^{1} \text { (T3) }\end{array}$ & $3960 \mathrm{a}$ & $2110.0 \mathrm{a}$ \\
\hline Application of compost $2 \mathrm{Mgha}^{-1}$ before sowing seeds (T4) & $3380 \mathrm{~b}$ & $1300.0 \mathrm{~b}$ \\
\hline Control (T5) & $2340 \mathrm{c}$ & $650.0 \mathrm{c}$ \\
\hline CV\% & 8.93 & 13.42 \\
\hline
\end{tabular}

Within the mean yield column, the means followed by the same letter are not significantly different

Since there is no significant difference between treatments with full dose of inorganic fertilizers and application of compost at the rate of $2 \mathrm{Mgha}^{-1}$ with half of DOA recommended basal application of inorganic fertilizer mixture.

When considered the cost for inorganic fertilizers, application of compost at the rate of $2 \mathrm{Mgha}^{-1}$ with half of DOA recommended basal application of inorganic fertilizer mixture can be used as farmer affordable economical fertilizer application method for finger millet cultivation.

\section{Determine the Effects of Weed Control Methods on Yield}

According to the results of both 2014/2015 and 2015/2016 Maha seasons; a very good yield can be obtained by practicing row sowing and two weeding at $3^{\text {rd }}$ and $6^{\text {th }}$ WAS. When practiced row sowing with application of selective herbicides the yield was better than which were with mulching and no weeding (Table 3). Also with the practice of random broadcasting, farmers could obtained better yield by practicing two weeding at $3^{\text {rd }}$ and $6^{\text {th }}$ WAS , same time lowest yield was showed with no weeding. 
Table 3. Yield with different weed control methods in 2014/2015 and 2015/2016 Maha seasons

\begin{tabular}{|c|c|c|}
\hline Treatments & $\begin{array}{l}\text { Mean yield } \\
\left(\mathrm{g} \mathrm{plot}^{-1}\right)\end{array}$ & $\begin{array}{l}\text { Mean yield (g } \\
\text { plot }^{-1} \text { ) }\end{array}$ \\
\hline Row sowing +2 manual weed removals at $3 \& 6$ WAS (T1) & $3187.5 \mathrm{a}$ & $1875.00 \mathrm{a}$ \\
\hline $\begin{array}{l}\text { Row sowing + selective herbicide application at } 3 \text { WAS } \\
\text { (T2) }\end{array}$ & $2537.5 \mathrm{bc}$ & $1256.25 \mathrm{~b}$ \\
\hline Row sowing +Mulching (T3) & $2300.0 \mathrm{c}$ & $1343.75 \mathrm{~b}$ \\
\hline Row sowing + no weeding (T4) & $1187.5 \mathrm{~d}$ & $250.00 \mathrm{c}$ \\
\hline $\begin{array}{l}\text { Random broadcasting }+2 \text { manual weed removals at } 3 \& 6 \\
\text { WAS (T5) }\end{array}$ & $2887.5 \mathrm{ab}$ & $1743.75 \mathrm{a}$ \\
\hline $\begin{array}{l}\text { Random broadcasting + selective herbicide application at } \\
3 \text { WAS (T6) }\end{array}$ & $2212.5 \mathrm{c}$ & $1187.5 \mathrm{~b}$ \\
\hline Random broadcasting +Mulching (T7) & $2037.5 \mathrm{c}$ & $462.5 \mathrm{c}$ \\
\hline $\begin{array}{l}\text { Random broadcasting+ no weeding (T8) } \\
\text { (Control) }\end{array}$ & $1100.0 \mathrm{~d}$ & $262.5 \mathrm{c}$ \\
\hline $\mathrm{CV} \%$ & 26.1 & 21.6 \\
\hline
\end{tabular}

The means followed by the same letter are not significantly different

With application of selective herbicides, the yield was better than with the application of mulch. Mulching of random broadcasted crop was difficult because there was no uniform space among plants. Results revealed that mulching is not much effective on yield of random broadcasted crop. Also the recorded yields were low in the no weeding treatments revealing that weeds caused an appreciable reduction in crop density, dry weight and depletion of nutrients (Pradhan et al. 2012). Amare et al. (2016) reported that the weeds are one of the major constraints limiting finger millet productivity and grain yield can be lowered considerably. In both the 2014/2015 and 2015/2016 Maha seasons, better yields were showed with row sowing in $30 \mathrm{~cm}$ spacing than by random broadcasting. The application of mulch also enhanced yields in the row sowed plots but the effect of mulches on yield was less with random broadcasting (Table 3). Nyende et al. (2001) and Pradhan et al. (2010) reported that planted in rows facilitate weed control in finger millet cultivation and leads for better 
yield. Ashrafi et al. (2009) also stated that availability of lesser space for weeds enhance the ability of the crop to compete for resources and lead for better growth and early space covering. Lall and Yadav (1982) reported that owing to initial slow growth of the finger millet favors weed growth, which causes more competition for sunlight, nutrient and water in early stages of growth lead in lowering productivity and causes yield losses. Mechanical and chemical methods are two main weed control methods in Finger millet. Although controlling weeds with these two methods is effective, they have some disadvantages or side effects that increase production costs when applied intensively (Fryer 1997).

Pandey et al. (2018), Prashanth Kumar et al. (2015) and Prithvi et al. (2015) reported that the application of herbicides effectively controls late emerged weeds in direct sown finger millet cultivation. Pandey et al. (2018) reported that all weed management practices significantly improve the growth and yield attributes of finger millet. The results were revealed that the use of any method to control weeds helps to get better yield. To get better yield of rain-fed finger millet two manual weeding's to reduce the effects of weed interference can be recommended.

\section{Effect of Developed SAPP on Yield of Rain- Fed Finger Millet}

Developed SAPP was tested at farmer fields in 2016/2017 and 2017/2018 Maha seasons. Six locations were established in both season and yields with transplanting or row sowing with the developed SAPP were higher than compared to the farmer practice (random broadcasted, not applied fertilizers and no weeding). Collected data of both seasons were shown in table 4.

Table 4: Yield data collected in 2016/2017 and 2017/2018 Maha seasons

\begin{tabular}{lll}
\hline Treatment & \multicolumn{2}{c}{ Yield (M ha-1) } \\
\cline { 2 - 3 } & $\mathbf{2 0 1 6 / 2 0 1 7}$ & $\mathbf{2 0 1 7} / \mathbf{2 0 1 8}$ \\
& Maha season & Maha season \\
\hline Transplanting + SAPP & $2.87 \mathrm{a}$ & $2.65 \mathrm{a}$ \\
Sowing seeds 30cm apart rows +SAPP & $2.62 \mathrm{~b}$ & $2.40 \mathrm{~b}$ \\
Farmer practice & $1.58 \mathrm{c}$ & $1.45 \mathrm{c}$ \\
CV\% & 7.43 & 7.95 \\
LsD (0.05) & 0.23 & 0.22 \\
\hline
\end{tabular}


According to the data of both seasons, when practiced transplanting with SAPP showed highest values and the lowest value showed with traditional farmer practice. In the 2016/2017 Maha season the yield enhancement of transplanting with SAPP compared to the traditional farmer practice was $181.64 \%$ and it was $182.76 \%$ in the2017/2018 Maha season, meanwhile the range of yield enhancement of SAPP with row sowing was $165.82 \%$ in the2016/2017 Maha season and it was $165.52 \%$ in 2017/2018 Maha season. Potential yield of used improved variety Rawana is between $2.5 \mathrm{M}$ and $3.0 \mathrm{M}$ per hectare (agridept.doa.gov.lk) and yield data showed that when practiced SAPP with transplanting, it is possible to reach potential yield for finger millet, under the rainfed farming condition. Average yield of finger millet at farmer's level is about1.

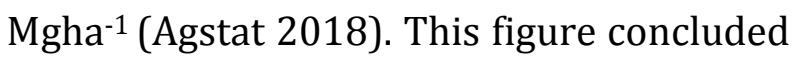
with finger millet cultivation both under rain fed and irrigated conditions. When considering the rain fed finger millet normally farmer's level yields might be lesser. According to collected data in both seasons yields with farmer practice were bit higher than national average yield, this may due to the farmer concentration with experimentation. Yield data showed that when practiced SAPP with transplanting gives highest yield meanwhile practiced
SAPP with sowing seeds in rows were showed significantly higher yield than the common farmer practice (Table 4). Therefore, can be assumed by using SAPP for rain fed finger millet cultivation, the yield can be enhanced by significant amount compare to the farmer practice.

\section{Conclusions}

Transplanting is the best practice to enhance the yield and also sowing seeds in rows leads for good yield. Variety Rawana which is a short duration, high yielding and less susceptible for diseases, is suitable for rain fed cultivation. Fertilizer application is important to get higher yield from rain fed finger millet cultivation. Combine use of improved variety Rawana, transplanting or row sowing after land preparation for crop establishment, use half of DOA recommended basal application of inorganic fertilizers with compost at the rate of $2 \mathrm{Mg}$ ha $^{-1}$ and two weed removals at 3 and 6 WAS as a package, enhance the yield of finger millet cultivation by more than $165 \%$ under rain-fed conditions compared to the cultivation practices use by the farmers in the Southern dry zone in Sri Lanka.

Conflicts of Interest: The authors have no conflicts of interest regarding this publication. 


\section{References}

Agstat 2018, 'Annual report on crop statistics', Department of Agriculture, Peradeniya, Sri Lanka

Agridept 2018, 'Cultivation of finger millet' https://doa.gov.lk/crops/finger millet

Amare, F, Etagegnehu, G \& Mariam, L 2016, 'Weed Control Practices and Inter-Row Spacing Influences on Weed Density and Grain Yield of Finger Millet (Eleusine Coracana L. Gaertn) in the Central Rift Valley of Ethiopia', International Journal of Research in Agriculture and Forestry Volume 3, Issue 9, September 2016, PP 1-7

Ashrafi, Z Y, Rahnavard, A \& Sedighen, S 2009, 'Analogy potential effects of planting methods and tank mixed herbicides', on wheat yield and weed populations: Journal of Agricultural Technology 5(2):391-403.

Fryer, J D \& Makepeace, R J 1997, 'Weed control observation when millet was planted at 10 and 15kg/ha' Hand book for millet cultivation: Blackwell scientific publication. Oxford, Page: 277.

IITA 1982, 'A annual report of International Institute of Tropical Agriculture for 1981', Ibandan, Nigeria.
Lall, M \& Yadev, L N S 1982, 'Critical time of weed removal in finger millet', Indian Journal of Weed Sciences 14: 85-88.

Liyanage, D P P, Millawithanachchi, M C, Samaranayake, B N, Malanie, L G \& Abeywikrama, L M 2015, 'Constraints of rainfed finger millet cultivation in Monaragala district in Sri Lanka', Annals of the Department of Agriculture, Sri Lanka: $17^{\text {th }}$ annual session: page 375 (Poster abstract)

Monje, D \& Raizada, M N 2011, 'Integration of Biotechnologies - Plant and Endophyte Relationships: Nutrient Management', Murray Moo-Young (ed.), Comprehensive Biotechnology, Second Edition, volume 4: pp. 713-727. Elsevier. http://www. scienc edirect.com/ science/article/pii/ B9780 080885049002646

Nyende, P, Tenywa, J S, Oryokot, J \& Kidoido, M 2001, 'Weed profiles and management assessment for increased finger millet production in Uganda', African Crop Science Journal, 9(3): 507-516.

Pandey, S, Lakra, R K, Nargis, K, Alam, P \& Puran, A N 2018, 'Weed Management on Direct Seeded Finger Millet (Eleusine coracana L.) Under Rainfed Condition of Jharkhand', International Journal of Current Microbiology and Applied Sciences ISSN: 2319-7706 Special Issue-7 pp. 844-850 
Journal homepage: http://www .ijcmas.com

Pradhan, A, Rajput, A S \& Thakur, A, 2010, 'Effect of weed management on growth and yield of finger millet', Indian Journal of Weed Science 42 (1\&2): 53-56.

Pradhan, A, Rajput, A S \& Thakur, A, 2012, 'Effect of weed management practices on finger millet under rainfed conditions', Indian Journal of Weed Science 44(2). 115117.

Prashanth, K, Shekara, M K, Yamuna, B G, \& Sunil, C M 2015, 'Crop Weed Competition for Nutrients by Weed and Drill Sown Finger millet (Eleusine coracana L. Gaertn.)', Journal of National Academy of Agriculture Science 33(3): 2049- 2054.

Prithvi, K B, Rao, A S \& Srinivasulu, K 2015, 'Weed management in transplanted ragi', Indian Journal of Weed Science 47(2): 214215.

Punyawardena, B V R, Bandara, T M J, Munasinghe, M A K \& Banda N J 2003, 'The Map of Agro Ecological Regions of Sri Lanka', Published by Department of Agriculture Sri Lanka.
Raizada, M N 2015, 'Increasing millet production in South Asia', from http:// www.idrc.ca/cifsrf

Raizada, M N 2016, “A Picture Book of Best Practices for Subsistence Farmers', South Asian version June 2016

SAS (Statistical Analysis System) Institute. Inc.2004, The SAS System for windows Portable Version 9.3.1 Cary NC, USA.

Senanayake, G 2001, 'Principles of Agronomy', (Published in Sinhala language), ISBN 955-97194-0-8:630DV21: AJ Printers, Dehiwala, Sri Lanka.

Yayeh, B \& Fekremariam 2014, 'Determination of Seed Rate and Inter Row Spacing for Finger Millet Production (Eleusine Coracana Gaertn.) in North Western Ethiopia', International Journal of Research \& Review (www.gkpublication.in) 1 Vol.1; Issue: 4: December 2014. 122-135 